\title{
Sarcomas in hereditary retinoblastoma
}

\author{
Ruth A Kleinerman ${ }^{1 *}$, Sara J Schonfeld ${ }^{1}$ and Margaret A Tucker ${ }^{1,2}$
}

\begin{abstract}
Children diagnosed with the hereditary form of retinoblastoma (Rb), a rare eye cancer caused by a germline mutation in the RB1 tumor suppressor gene, have excellent survival, but face an increased risk of bone and soft tissue sarcomas. This predisposition to sarcomas has been attributed to genetic susceptibility due to inactivation of the RB1 gene as well as past radiotherapy for $\mathrm{Rb}$. The majority of bone and soft tissue sarcomas among hereditary $\mathrm{Rb}$ survivors occur in the head, within the radiation field, but they also occur outside the radiation field. Sarcomas account for almost half of the second primary cancers in hereditary Rb survivors, but they are very rare following non-hereditary Rb. Sarcomas among hereditary Rb survivors arise at ages similar to the pattern of occurrence in the general population. There has been a trend over the past two decades to replace radiotherapy with chemotherapy and other focal therapies (laser or cryosurgery), and most recently, chemosurgery in order to reduce the incidence of sarcomas and other second cancers in Rb survivors. Given the excellent survival of most Rb patients treated in the past, it is important for survivors, their families and health care providers to be aware of the heightened risk for sarcomas in hereditary patients.
\end{abstract}

Keywords: Retinoblastoma, Soft tissue sarcoma, Bone sarcoma, Radiotherapy, Epidemiology, RB1 gene, Hereditary

\section{Introduction}

Children diagnosed with the hereditary form of retinoblastoma ( $\mathrm{Rb})$, a rare eye cancer caused by a germline mutation in the RB1 tumor suppressor gene, have excellent survival, but face an increased risk for the development of sarcomas, both soft tissue (STS) and bone. This predisposition to sarcomas in retinoblastoma survivors has been attributed to genetic susceptibility as well as past radiation treatment for $\mathrm{Rb}$.

\section{Retinoblastoma epidemiology}

Retinoblastoma is a rare pediatric cancer of the eye with an autosomal dominant inheritance pattern. It is caused by mutations in the $R B 1$ tumor suppressor gene, located on chromosome 13q14 with very high penetrance and expressivity [1]. Approximately $80 \%-90 \%$ of $R B 1$ gene carriers develop ocular tumors. This gene encodes the cell cycle regulatory retinoblastoma gene protein $(\mathrm{pRb})$, controls cellular differentiation during both embryogenesis and in adult tissues, regulates apoptotic cell death,

\footnotetext{
*Correspondence: kleinerr@mail.nih.gov

'Epidemiology and Biostatistics Program Division of Cancer Epidemiology and Genetics, National Cancer Institute, National Institutes of Health, 6120 Executive Boulevard, Rockville, MD 20852, USA

Full list of author information is available at the end of the article
}

maintains cell cycle arrest and preserves chromosome stability [2].

Retinoblastoma occurs in two forms: hereditary (30-40\%) and non-hereditary (60-70\%). Hereditary retinoblastoma is caused by a germline mutation in one allele of the RB1 gene and an acquired somatic mutation in the other allele, whereas the non-hereditary form is caused by somatic mutations in both alleles. The hereditary form is characterized by disease in both eyes (bilateral $\mathrm{Rb}$ ) and is typically diagnosed before 12 months of age, whereas, the nonhereditary form affects one eye (unilateral $\mathrm{Rb}$ ) and is diagnosed between $2-5$ years of age. About $10-15 \%$ of patients with unilateral $\mathrm{Rb}$, however, carry a germline mutation and are considered hereditary. This difference in diagnosis age led Knudson to develop the two-hit theory [3], in which only one additional mutation is needed for hereditary $\mathrm{Rb}$ and two hits or somatic mutations are needed for nonhereditary $\mathrm{Rb}$ [4]. The age-adjusted annual incidence rate of retinoblastoma is 3.1 per $10^{7}$ with a 5 -year relative survival of $97.5 \%$ in the U.S. [5]. Treatment for Rb has historically consisted primarily of radiotherapy (both external beam and radioactive plaques), enucleation, chemotherapy, focal therapies such as laser or cryotherapy, or a combination of these modalities.

\section{Ciomed Central}

(c) 2012 Kleinerman et al.; licensee BioMed Central Ltd. This is an Open Access article distributed under the terms of the Creative Commons Attribution License (http://creativecommons.org/licenses/by/2.0), which permits unrestricted use, distribution, and reproduction in any medium, provided the original work is properly cited. 


\section{Subsequent malignancies after retinoblastoma}

Long-term survivors of hereditary retinoblastoma are at an increased 20-fold risk of developing and dying from a subsequent non-ocular cancer, primarily bone and soft tissue sarcomas, melanoma and brain tumors [6,7]. Survivors of non-hereditary $\mathrm{Rb}$ are at much lower risk of a subsequent primary cancer, similar to the risk in the general population [8-10]. The risk for sarcomas in hereditary patients has been attributed to genetic susceptibility and past treatment with radiation $[8,11,12]$. In addition to radiotherapy, chemotherapy, specifically alkylating agents, has been associated with the risk of bone cancer after $\mathrm{Rb}[6,13,14]$, but less so for soft tissue sarcomas [15].

\section{Bone sarcomas after retinoblastoma Patterns of risk}

Bone sarcomas are one of the most common second primary cancers occurring after hereditary retinoblastoma accounting for $25 \%-30 \%$ of all second primary cancers $[6-8,16,17]$. Bone sarcomas are typically diagnosed in $\mathrm{Rb}$ survivors between 10 and 20 years of age, similar to the incidence pattern in the general population [5]. In these studies, the majority of bone sarcomas occurred within the radiation field in the head region, but up to $40 \%$ was diagnosed outside the treatment field, primarily in the lower legs $[8,11,17]$.

Table 1 presents risks for bone sarcomas from epidemiologic cohort studies including at least 100 hereditary Rb survivors. The standardized incidence and mortality rates for bone sarcomas are increased several hundred-fold compared to population rates, due to the rarity of these tumors in the general population. A much lower risk for bone sarcomas was observed in the one cohort study that included non-irradiated survivors and began follow-up 25 years after Rb diagnosis [10]. It has been estimated that the cumulative incidence of bone sarcoma following retinoblastoma is $7 \%$ at 20 years $[13,18]$. Osteosarcoma is the most common type of bone sarcoma reported after $\mathrm{Rb}$, but both chondrosarcoma and Ewing sarcoma have been reported as well $[19,20]$, although risk estimates are not available for these other two types.

\section{Treatment for $R b$ and risk of bone sarcomas}

Both high-dose radiation and increasing cumulative dose of chemotherapy, mainly alkylating agents (cyclophosphamide and triethylenemelamine or TEM), have been linked to the occurrence of bone sarcomas following hereditary Rb $[13,14]$. Higher risks have been noted for the combination of radiotherapy and chemotherapy compared to either treatment alone [6-8,13,14]. An earlier study of British $\mathrm{Rb}$ patients provided some evidence that cyclophosphamide may increase the effect of radiotherapy on the risk of bone sarcoma [8].
In a case-control study of bone and soft tissue sarcomas after hereditary $\mathrm{Rb}$, risk increased with increasing dose up to 10.7 -fold at doses greater than 60 Gy [11]. The mean dose to the head among cases was $32.8 \mathrm{~Gy}$, whereas the lower limbs had received virtually no radiation $(<0.1 \mathrm{~Gy})$. In an update of that study, the location of 75 bone sarcomas was skull and face (61\%), lower limbs (29\%), trunk (7.6\%), and unknown location (3.8\%) [7].

Based on a series of 155 osteosarcomas following hereditary $\mathrm{Rb}$ identified from the literature and one institute, investigators reported that the mean age of onset was related to the osteosarcoma location [21]. Sarcomas occurring in the radiation field were diagnosed one year earlier compared to those diagnosed outside the field (mean age $=12.2$ years [range $3-35$ ] vs. mean age $=13.4$ years [range 4-22]. This age difference suggested to the investigators that different biologic mechanisms may be associated with the development of bone sarcomas depending upon the location in the body.

Studies of other pediatric malignancies have also reported an increased risk for second osteosarcomas following radiation and chemotherapy treatment for a first cancer (for a detailed review of radiation-related sarcomas, see Berrington de Gonzalez et al. in this issue).

\section{Soft Tissue Sarcomas \\ Patterns of risk}

Soft tissue sarcomas (STS) are also one of the most common subsequent cancers following hereditary $\mathrm{Rb}$ accounting for $12 \%$ up to $32 \%$ of all second cancers $[6,7,16]$. In one large cohort study, an increased risk for STS was first observed within 10 years of $\mathrm{Rb}$ diagnosis and continued through adult life up to 50 years after $\mathrm{Rb}$, with specific subtypes occurring at similar ages as in the general population [22,23]. Fifty years after radiation treatment for hereditary $\mathrm{Rb}$, the cumulative risk of developing a STS was $13.1 \%$, and the cumulative incidence for a STS inside the radiation field was higher than outside the field (8.9\% vs. 5.1\%) [22]. Table 2 presents the incidence and mortality due to STS after Rb in cohort studies of at least 100 hereditary Rb survivors.

\section{Subtype heterogeneity}

STS diagnosed in $\mathrm{Rb}$ patients comprise a heterogeneous group of tumors of fat, cartilage and muscle; however, only one study has evaluated the risk of STS by histology after hereditary $\mathrm{Rb}$ [22]. Leiomyosarcoma (LMS) constituted the most common type of STS after Rb, with the majority diagnosed 30 and more years after $\mathrm{Rb}$. This is consistent with LMS being one of the most common STS in the general population [23]. Although many LMS occurred in the head and neck region, the majority of LMS in females were diagnosed in the uterus [24]. Loss of heterozygosity in $R B 1$ has been reported in uterine 
Table 1 Summary of bone sarcoma after retinoblastoma in cohort studies of 100 or more hereditary retinoblastoma survivors

\begin{tabular}{|c|c|c|c|c|c|c|c|}
\hline Study & $\begin{array}{l}\text { Study design, Years } \\
\text { of } \mathrm{Rb} \text { diagnosis }\end{array}$ & $\begin{array}{l}\text { No. subjects with } \\
\text { hereditary } \\
\text { retinoblastoma }\end{array}$ & $\begin{array}{l}\text { Years of follow-up: } \\
\text { median/mean }\end{array}$ & $\begin{array}{l}\text { No. bone } \\
\text { sarcoma } \\
\text { cases }\end{array}$ & $\mathrm{O} / \mathrm{E}, 95 \% \mathrm{Cl}$ & $\begin{array}{l}\text { O/E by treatment for } \\
\text { retinoblastoma }\end{array}$ & Comments \\
\hline \multicolumn{8}{|l|}{ 1a. Incidence } \\
\hline $\begin{array}{l}\text { Kleinerman } 2005 \text { [7] US } \\
\text { Two US medical centers }\end{array}$ & $\begin{array}{l}\text { Hospital-based } \\
\text { 1914-1984 }\end{array}$ & 963 1-yr survivors & Mean: 25 & 75 & $360(283-451)$ & $\begin{array}{l}\text { Any radiation: } 406 \text { (318-511) } \\
\text { No radiation: } 69 \text { (8.4-250) } \\
\text { Radiation + chemotherapy: } \\
539 \text { (384-733); Radiation, } \\
\text { no chemotherapy: } \\
302 \text { (205-428) }\end{array}$ & $A E R=29.6$ \\
\hline $\begin{array}{l}\text { Reulen } 2011 \text { [16] British } \\
\text { Childhood Cancer Survivor } \\
\text { Study, UK }\end{array}$ & $\begin{array}{l}\text { Population-based } \\
\text { 1940-1991 }\end{array}$ & $N A^{*}, 5$-yr survivors & Mean: 26 & 35 & $289(209-402)$ & NA & $\begin{array}{l}\text { AER }=23 ;{ }^{*} \text { No. of Rb survivors } \\
\text { not given but there are estimated } \\
\text { to be } 809 \text { hereditary Rb subjects } \\
\text { based on MacCarthy et al. [44] }\end{array}$ \\
\hline $\begin{array}{l}\text { Marees } 2008 \text { [6] Netherlands } \\
\text { Dutch Retinoblastoma } \\
\text { Registry }\end{array}$ & $\begin{array}{l}\text { Registry -based } \\
\text { 1945-2005 }\end{array}$ & 298 survivors & Median: 22 & 16 & $314(180-511)$ & $\begin{array}{l}\text { Radiation only: } 302 \text { (130-596) } \\
\text { Radiation + chemotherapy: } \\
586 \text { (215-1275); Surgery only: } \\
75 \text { (1.9-421) }\end{array}$ & $\mathrm{AER}=23$ \\
\hline $\begin{array}{l}\text { Tucker } 1987 \text { [14] US } \\
\text { Late Effects Study Group }\end{array}$ & $\begin{array}{l}\text { Hospital-based } \\
1945-1979\end{array}$ & 319 2-yr survivors & Mean: 7 & 12 & $999(515-1745)$ & & *Hereditability not specified \\
\hline 1b. Mortality & & & & & SMR, $95 \% \mathrm{Cl}$ & $\begin{array}{l}\text { SMR by treatment for } \\
\text { retinoblastoma }\end{array}$ & \\
\hline $\begin{array}{l}\text { Yu } 2009 \text { [12] US } \\
\text { Two medical centers }\end{array}$ & $\begin{array}{l}\text { Hospital-based } \\
\text { 1914-1996 }\end{array}$ & 1092 1-yr survivors & Median: 29 & 56 & $595(449-773)$ & Radiation: 673 (506-879) & $\begin{array}{l}\mathrm{AER}=19.8 ;{ }^{*} \text { No difference between } \\
\text { males and females }\end{array}$ \\
\hline $\begin{array}{l}\text { Marees } 2009 \text { [46] Netherlands } \\
\text { Dutch Retinoblastoma Registry }\end{array}$ & $\begin{array}{l}\text { Registry-based } \\
1862-2005\end{array}$ & 337 (alive in 1961) & $\begin{array}{l}\text { Median: } 26 \text { yr } \\
\text { Follow-up } \\
\text { 1961-2005 }\end{array}$ & 11 & $289(144-517)$ & $\begin{array}{l}\text { Radiation only: } 266 \text { (72.2-680) } \\
\text { Radiation + chemotherapy: } \\
659 \text { (179-1686); Surgery only: } \\
124 \text { (15-449) }\end{array}$ & $\begin{array}{l}\text { Majority deaths from bone cancer } \\
\text { occur within first } 30 \text { years }\end{array}$ \\
\hline $\begin{array}{l}\text { Acquaviva } 2006 \text { [46] Italian } \\
\text { Retinoblastoma Registry }\end{array}$ & $\begin{array}{l}\text { Registry-based } \\
\text { 1923-2003 }\end{array}$ & 408 & Median: 11 & 9 & $392(204-753)$ & NA & \\
\hline $\begin{array}{l}\text { Fletcher } 2004 \text { [10] Patients } \\
\text { from British hospitals and } \\
\text { linkage with national registry }\end{array}$ & $\begin{array}{l}\text { Hospital-based } \\
1873-1950\end{array}$ & 144 25-yr survivors & $\begin{array}{l}\text { Follow up began } \\
\text { in } 1940 \\
\text { Median age: } 60\end{array}$ & 1 & $32.4(0.82-180)$ & NA & $\begin{array}{l}\text { *Radiation was not typically used } \\
\text { to treat } \mathrm{Rb} \text { during these years }\end{array}$ \\
\hline
\end{tabular}

Abbreviations: $\mathrm{O}=$ observed number of bone sarcomas; $\mathrm{E}=$ expected number of bone sarcomas; $\mathrm{Cl}=$ confidence intervals; $\mathrm{AER}=$ absolute excess risk per 10,000 persons, yr $=$ year; $S \mathrm{MR}=\mathrm{standardized}$ mortality ratio; $\mathrm{NA}$ not available. 
Table 2 Summary of soft tissue sarcoma after retinoblastoma in cohort studies of $\mathbf{1 0 0}$ or more hereditary retinoblastoma survivors

\begin{tabular}{|c|c|c|c|c|c|c|c|}
\hline Study & $\begin{array}{l}\text { Study Design Years } \\
\text { of } \mathrm{Rb} \text { diagnosis }\end{array}$ & $\begin{array}{l}\text { Number of subjects } \\
\text { with hereditary } \\
\text { retinoblastoma }\end{array}$ & $\begin{array}{l}\text { Years of follow-up: } \\
\text { median/mean }\end{array}$ & $\begin{array}{l}\text { No. of Soft } \\
\text { tissue } \\
\text { sarcomas }\end{array}$ & $\mathrm{O} / \mathrm{E}, 95 \% \mathrm{Cl}$ & $\begin{array}{l}\text { O/E by treatment for } \\
\text { retinoblastoma }\end{array}$ & Comments \\
\hline \multicolumn{8}{|l|}{ 2a. Incidence } \\
\hline $\begin{array}{l}\text { Kleinerman } 2007 \text { [22] US } \\
\text { Two medical centers }\end{array}$ & $\begin{array}{l}\text { Hospital-based } \\
\text { 1914-1984 }\end{array}$ & 9631 -yr survivors & Mean: 25 & 69 & $184(143-233)$ & $\begin{array}{l}\text { Any radiation: } 212 \text { (164-270); } \\
\text { No radiation: } 47 \text { (9.4-137); Any } \\
\text { chemotherapy: } 236 \text { (161-333); } \\
\text { No chemotherapy: } 193 \\
\text { (133-271) }\end{array}$ & $\begin{array}{l}\text { AER }=27 * \text { No evidence of risk } \\
\text { modification by sex *SIRs highest } \\
\text { within first } 10 \text { years but remained } \\
\text { significantly elevated } \geq 30\end{array}$ \\
\hline $\begin{array}{l}\text { Reulen } 2011 \text { [16] British } \\
\text { Childhood Cancer } \\
\text { Survivor Study }\end{array}$ & $\begin{array}{l}\text { Population-based } \\
\text { 1940-1991 }\end{array}$ & NA, 5-yr survivors & Mean: 26 & 16 & N/A & N/A & $\begin{array}{l}\text { Rates increase over time since Rb } \\
\text { (highest >25) }\end{array}$ \\
\hline $\begin{array}{l}\text { Marees } 2008 \text { [6] Netherlands } \\
\text { Dutch Retinoblastoma Registry }\end{array}$ & $\begin{array}{l}\text { Registry-based } \\
1945-2005\end{array}$ & 298 & Median: 22 & 20 & $243(148-375)$ & $\begin{array}{l}\text { Radiation only: } 303 \text { (161-517) } \\
\text { Radiation + chemotherapy: } 354 \\
\text { (129-770) Surgery only: } \\
48.4 \text { (1.23-270) }\end{array}$ & $\begin{array}{l}\text { AER }=29 ; \text { SIRs elevated in all time } \\
\text { periods ( } 3 \text { cases } \geq 40 \text { ) }\end{array}$ \\
\hline $\begin{array}{l}\text { Tucker } 1987 \text { [14] US } \\
\text { Late Effects Study Group }\end{array}$ & $\begin{array}{l}\text { Hospital-based } \\
\text { 1945-1979 }\end{array}$ & $\begin{array}{l}319 \text { 2-yr survivors } \\
\text { (hereditability not } \\
\text { specified) }\end{array}$ & Mean: 7 & 4 & $235(64-602)$ & & All cases observed among females \\
\hline 2b. Mortality & & & & & SMR, $95 \% \mathrm{Cl}$ & $\begin{array}{l}\text { SMR by treatment for } \\
\text { retinoblastoma }\end{array}$ & \\
\hline $\begin{array}{l}\text { Yu } 2009 \text { [12] US } \\
\text { Two medical centers }\end{array}$ & $\begin{array}{l}\text { Hospital-based } \\
\text { 1914-1996 }\end{array}$ & 1092 1-yr survivors & Median: 29 & 31 & $329(223-467)$ & Any Radiation 395 (268-560) & $\begin{array}{l}\text { AER }=10.9 ; \text { SMR is higher for women } \\
\text { vs men (not statistically significant) }\end{array}$ \\
\hline $\begin{array}{l}\text { Marees } 2009 \text { [45] Netherlands } \\
\text { Dutch Retinoblastoma Registry }\end{array}$ & $\begin{array}{l}\text { Registry-based } \\
1862-2005\end{array}$ & 337 & $\begin{array}{l}\text { Median: } 26 \\
\text { Follow-up } \\
\text { 1961-2005 }\end{array}$ & 13 & $276(147-472)$ & $\begin{array}{l}\text { Radiation only: } 311 \text { (101-725) } \\
\text { Rad + chemotherapy: } 940 \\
\text { (345-2064); Surgery only: } \\
\text { 85.2 (10.3-308) }\end{array}$ & $\begin{array}{l}\text { *Deaths observed up to } \geq 50 \text { years } \\
\text { after RB *SMR peaks at } 20-29 \text { years } \\
\text { but SMRs significantly elevated in all } \\
\text { time periods }\end{array}$ \\
\hline $\begin{array}{l}\text { Acquaviva } 2006 \text { [46] Italian } \\
\text { Retinoblastoma Registry }\end{array}$ & $\begin{array}{l}\text { Registry-based } \\
1923-2003\end{array}$ & 408 & Median: 12 & 6 & $453(203.5-1008)$ & NA & \\
\hline $\begin{array}{l}\text { Fletcher } 2004 \text { [10] UK Patients } \\
\text { from British hospitals; linkage } \\
\text { with national registry }\end{array}$ & $\begin{array}{l}\text { Hospital-based } \\
1873-1950\end{array}$ & 144 25-yr survivors & $\begin{array}{l}\text { Median attained } \\
\text { age: } 60 ; \text { Follow-up } \\
\text { began in } 1940\end{array}$ & 4 & $110(29-281)$ & NA & $\begin{array}{l}\text { *Treatment not available, but radiation } \\
\text { was not typically used during these } \\
\text { years of } \mathrm{Rb} \text { diagnosis }\end{array}$ \\
\hline
\end{tabular}

Abbreviations: $\mathrm{O}=$ observed number of soft tissue sarcomas; $\mathrm{E}=$ expected number of soft tissue sarcomas; $\mathrm{Cl}=$ confidence intervals; $\mathrm{AER}=$ absolute excess risk per 10,000 persons, $y r=$ year; $\mathrm{SMR}=$ standardized mortality ratio; $\mathrm{NA}$ not available. 
LMS [25], which may confer an increased susceptibility to this tumor in this population. LMS of other pelvic sites have also been reported after $\mathrm{Rb}$ [26], and there have been several case reports of LMS diagnosed in the bladder [27,28].

Very high risks have also been observed for fibrosarcomas, rhabdomyosarcomas and pleomorphic sarcomas within the first 10 years after $\mathrm{Rb}$ [22,29]. These histologic types comprised the majority of STS that were diagnosed in or near the field of radiation, in contrast to LMS, which were more likely to occur outside the radiation field (Table 3). Only 10\% of rhabdomyosarcomas arise in the soft tissue of the head, neck or face in the general population, whereas all of the rhabdomyosarcomas arose in the head following radiation for $\mathrm{Rb}$ [22].

An increased risk for liposarcomas that began 10 years after diagnosis of hereditary $\mathrm{Rb}$ was observed in the study by Kleinerman et al. [22]. Lipomas, a benign tumor of fat tissue, have also been reported to be increased in that cohort, and the investigators noted a possible association between lipomas and subsequent risk of a soft tissue sarcoma [30]. Following this observation, a $R B 1$ mutation was identified in lipomas from hereditary $\mathrm{Rb}$ patients [31,32].

It has been suggested that females may be at higher risk of STS after hereditary Rb [9], but studies of $\mathrm{Rb}$ survivors have not consistently reported a higher risk among females. Males have a higher rate of $\mathrm{Rb}$ in the general population and all liposarcomas and lipomas occurred in males in the cohort in which they were evaluated $[22,30]$.

\section{Treatment for $R b$ and risk of STS}

Although both radiotherapy and chemotherapy for hereditary $\mathrm{Rb}$ have been associated with an increased risk for STS, the evidence is more consistent for radiotherapy. (For a detailed review of radiation-related sarcoma, see Berrington de Gonzalez et al. in this issue). Wong et al. demonstrated a radiation dose-response for STS whereby risk increased with dose up to a significant 11-fold increased risk at $\geq 60$ Gy [11]. The risk for STS was not

Table 3 Location of soft tissue sarcoma after radiotherapy for retinoblastoma*

\begin{tabular}{llll}
\hline STS subtype & In-field & Out-of-field & Total \\
\hline Leiomyosarcoma & $8(38.1)$ & $13(61.9)$ & $21(100)$. \\
Fibrosarcoma & $13(100)$. & 0 & $13(100)$. \\
Pleomorphic sarcoma & $11(100)$. & 0 & $11(100)$. \\
Rhabdomyosarcoma & $7(100)$. & 0 & $7(100)$. \\
Liposarcoma & $1(33.3)$ & $2(66.7)$ & $3(100)$. \\
Other STS & $8(80.0)$ & $2(20.0)$ & $10(100)$. \\
Total & $48(72.7)$ & $18(27.3)$ & $66(100)$. \\
\hline
\end{tabular}

*Based on data from Kleinerman et al. [22]. associated with increasing alkylating agent score in the same cohort [22], whereas in another study of STS after all types of pediatric malignancies, including $\mathrm{Rb}$, the risk for STS increased significantly with cumulative dose of alkylating agents, adjusted for radiation exposure [15]. Increased risks of STS have also been noted following surgery only for hereditary $\mathrm{Rb}[6,10]$.

\section{Molecular evidence for an association of sarcomas with RB1}

In additional to the epidemiologic evidence of an excess risk for both bone and STS in hereditary Rb patients, structural alterations of the $R B 1$ gene are well documented in primary bone sarcomas [33] and soft tissue sarcomas [34-36]. Most of the bone and soft tissue sarcomas diagnosed in hereditary $\mathrm{Rb}$ patients have complex karyotypes, including fibrosarcoma, LMS, pleomorphic sarcoma, liposarcoma and osteosarcoma that are all related to inherited defects in the RB pathway [37]. A comprehensive review by Burkhart and Sage of cellular mechanisms of tumor suppression by the retinoblastoma gene discusses the loss of $R B 1$ function and cancer progression [2].

\section{Conclusion}

Hereditary $\mathrm{Rb}$ patients are at significant risk of developing a sarcoma due to past radiation treatment and genetic susceptibility. Sarcomas account for approximately $40 \%$ to $60 \%$ of second cancers in hereditary Rb survivors. There is convincing epidemiologic evidence linking past radiotherapy with sarcomas in hereditary patients. Risk of bone and STS begins within 10 years of treatment for hereditary $\mathrm{Rb}$ and continues throughout adulthood, most notably for STS.

Recognition of the increased risk for sarcomas associated with past radiotherapy has influenced the current treatment of retinoblastoma with a trend towards greater use of chemotherapy, focal therapies, and most recently, chemosurgery [38-40]. In addition, guidelines for imaging children for pre-treatment diagnostic evaluation of $\mathrm{Rb}$ without the use of ionizing radiation have been recommended to reduce the risk of second cancers in $\mathrm{Rb}$ patients [41]. However, the risk for bone sarcomas and STS remains, reflecting the genetic predisposition to these sarcomas due to loss of heterozygosity in the RB1 gene. Patients who were treated in 1960s and 1970s with radiotherapy are still at risk in their adult years for the development of STS. Given the excellent survival of most retinoblastoma patients, it is important for survivors, their families and health care providers to be aware of these risks, especially for hereditary patients [42]. There is on-going research to try to identify whether specific RB1 mutations or location of mutations predispose to sarcomas, which could lead to identification of those survivors at greatest risk [43]. The development of 
comprehensive guidelines for long-term follow-up that are specifically tailored for detection of sarcomas and other second primary cancers in retinoblastoma survivors are also needed, especially for those patients who received radiotherapy in the past.

\section{Abbreviations}

$\mathrm{Rb}$ : retinoblastoma; STS: soft tissue sarcoma; LMS: leiomyosarcoma.

\section{Competing interests}

The authors declare that they have no competing interests.

\section{Author contributions}

RK and SS participated in the review of existing data, RK, SS and MT contributed to the interpretation of the data, and all participated in the draft of the manuscript. All authors read and approved the final manuscript.

\section{Acknowledgement}

This research was supported by the Intramural Research Program of the National Institutes of Health, National Cancer Institute.

\section{Author details}

${ }^{1}$ Epidemiology and Biostatistics Program Division of Cancer Epidemiology and Genetics, National Cancer Institute, National Institutes of Health, 6120 Executive Boulevard, Rockville, MD 20852, USA. ${ }^{2}$ Human Genetics Program, Division of Cancer Epidemiology and Genetics, National Cancer Institute, National Institutes of Health, 6120 Executive Boulevard, Rockville, MD 20852, USA.

Received: 7 October 2011 Accepted: 23 January 2012

Published: 4 October 2012

\section{References}

1. Harbour JW: Molecular basis of low-penetrance retinoblastoma. Arch Ophthalmol 2001, 119:1699-1704.

2. Burkhart DL, Sage J: Cellular mechanisms of tumour suppression by the retinoblastoma gene. Nat Rev Cancer 2008, 8:671-682.

3. Knudson AG Jr: Mutation and cancer: statistical study of retinoblastoma. Proc Natl Acad Sci U S A 1971, 68:820-823.

4. Little MP, Kleinerman RA, Stiller CA, Li G, Kroll ME, Murphy MF: Analysis of retinoblastoma age incidence data using a fully stochastic cancer model. Int J Cancer 2011, 130:631-640.

5. SEER: Cancer Statistics Review. 2008 [http://seer.cancer.gov/csr/1975_2008].

6. Marees T, Moll AC, Imhof SM, de Boer MR, Ringens PJ, van Leeuwen FE: Risk of second malignancies in survivors of retinoblastoma: more than 40 years of follow-up. J Natl Cancer Inst 2008, 100:1771-1779.

7. Kleinerman RA, Tucker MA, Tarone RE, Abramson DH, Seddon JM, Stovall M, Li FP, Fraumeni JF Jr: Risk of new cancers after radiotherapy in long-term survivors of retinoblastoma: an extended follow-up. J Clin Oncol 2005, 23:2272-2279.

8. Draper GJ, Sanders BM, Kingston JE: Second primary neoplasms in patients with retinoblastoma. Br J Cancer 1986, 53:661-671.

9. Eng C, Li FP, Abramson DH, Ellsworth RM, Wong FL, Goldman MB, Seddon J, Tarbell N, Boice JD Jr: Mortality from second tumors among long-term survivors of retinoblastoma. J Natl Cancer Inst 1993, 85:1121-1128.

10. Fletcher $\mathrm{O}$, Easton $\mathrm{D}$, Anderson $\mathrm{K}$, Gilham $\mathrm{C}$, Jay M, Peto J: Lifetime risks of common cancers among retinoblastoma survivors. J Natl Cancer Inst 2004, 96:357-363.

11. Wong FL, Boice JD Jr, Abramson DH, Tarone RE, Kleinerman RA, Stovall M, Goldman MB, Seddon JM, Tarbell N, Fraumeni JF Jr, Li FP: Cancer incidence after retinoblastoma. Radiation dose and sarcoma risk. JAMA 1997, 278:1262-1267.

12. Yu CL, Tucker MA, Abramson DH, Furukawa K, Seddon JM, Stovall M, Fraumeni JF Jr, Kleinerman RA: Cause-specific mortality in long-term survivors of retinoblastoma. J Natl Cancer Inst 2009, 101:581-591.

13. Hawkins MM, Wilson LM, Burton HS, Potok MH, Winter DL, Marsden HB, Stovall MA: Radiotherapy, alkylating agents, and risk of bone cancer after childhood cancer. J Natl Cancer Inst 1996, 88:270-278.

14. Tucker MA, D'Angio GJ, Boice JD Jr, Strong LC, Li FP, Stovall M, Stone BJ, Green DM, Lombardi F, Newton W, et al: Bone sarcomas linked to radiotherapy and chemotherapy in children. N Engl J Med 1987, 317:588-593.

15. Jenkinson HC, Winter DL, Marsden HB, Stovall MA, Stevens MC, Stiller CA, Hawkins MM: A study of soft tissue sarcomas after childhood cancer in Britain. Br J Cancer 2007, 97:695-699.

16. Reulen RC, Frobisher C, Winter DL, Kelly J, Lancashire ER, Stiller CA Pritchard-Jones K, Jenkinson HC, Hawkins MM: Long-term risks of subsequent primary neoplasms among survivors of childhood cancer. JAMA 2011, 305:2311-2319.

17. Woo Kl, Harbour JW: Review of 676 second primary tumors in patients with retinoblastoma: association between age at onset and tumor type. Arch Ophthalmol 2010, 128:865-870.

18. Kleinerman $\mathrm{R}, \mathrm{Yu} \mathrm{CL}$, Little MP, Abramson DH, Seddon JH, Tucker MA: Variation of second cancer risk by family history of retinoblastoma among long-term survivors. Journal of Clin Oncol 2012, 30:950-957.

19. Cope JU, Tsokos M, Miller RW: Ewing sarcoma and sinonasal neuroectodermal tumors as second malignant tumors after retinoblastoma and other neoplasms. Med Pediatr Oncol 2001, 36:290-294.

20. Moll AC, Imhof SM, Schouten-Van Meeteren AY, Kuik DJ, Hofman P, Boers $\mathrm{M}$ : Second primary tumors in hereditary retinoblastoma: a register-based study, 1945-1997: is there an age effect on radiation-related risk? Ophthalmology 2001, 108:1109-1114.

21. Chauveinc L, Mosseri V, Quintana E, Desjardins L, Schlienger P, Doz F. Dutrillaux B: Osteosarcoma following retinoblastoma: age at onset and latency period. Ophthalmic Genet 2001, 22:77-88.

22. Kleinerman RA, Tucker MA, Abramson DH, Seddon JM, Tarone RE, Fraumeni JF Jr: Risk of soft tissue sarcomas by individual subtype in survivors of hereditary retinoblastoma. J Nat/ Cancer Inst 2007, 99:24-31.

23. Toro JR, Travis LB, Wu HJ, Zhu K, Fletcher CD, Devesa SS: Incidence patterns of soft tissue sarcomas, regardless of primary site, in the surveillance, epidemiology and end results program, 1978-2001: An analysis of 26,758 cases. Int J Cancer 2006, 119:2922-2930.

24. Francis $\mathrm{JH}$, Kleinerman RA, Seddon JM, Abramson DH: Increased risk of secondary uterine leiomyosarcoma in hereditary retinoblastoma. Gynecol Oncol 2011, 124:254-259.

25. Dei Tos AP, Maestro R, Doglioni C, Piccinin S, Libera DD, Boiocchi M, Fletcher CD: Tumor suppressor genes and related molecules in leiomyosarcoma. Am J Pathol 1996, 148:1037-1045.

26. Venkatraman L, Goepel JR, Steele K, Dobbs SP, Lyness RW, McCluggage WG: Soft tissue, pelvic, and urinary bladder leiomyosarcoma as second neoplasm following hereditary retinoblastoma. J Clin Pathol 2003, 56:233-236

27. Bleoo SL, Godbout R, Rayner D, Tamimi Y, Moore RB: Leiomyosarcoma of the bladder in a retinoblastoma patient. Urol Int 2003, 71:118-121.

28. Brucker B, Ernst L, Meadows A, Zderic S: A second leiomyosarcoma in the urinary bladder of a child with a history of retinoblastoma 12 years following partial cystectomy. Pediatr Blood Cancer 2006, 46:811-814.

29. Cebulla CM, Kleinerman RA, Alegret A, Kulak A, Dubovy SR, Hess DJ, Murray TG: Rapid Appearance of Rhabdomyosarcoma after Radiation and Chemotherapy for Retinoblastoma: A Clinicopathologic Correlation. Retin Cases Brief Rep 2009, 3:343-346.

30. Li FP, Abramson DH, Tarone RE, Kleinerman RA, Fraumeni JF Jr, Boice JD Jr: Hereditary retinoblastoma, lipoma, and second primary cancers. J Natl Cancer Inst 1997, 89:83-84.

31. Rieder H, Lohmann D, Poensgen B, Fritz B, Aslan M, Drohm D, Strombach Angersbach FJ, Rehder $\mathrm{H}$ : Loss of heterozygosity of the retinoblastoma (RB1) gene in lipomas from a retinoblastoma patient. J Natl Cancer Inst 1998, 90:324-326.

32. Genuardi M, Klutz M, Devriendt K, Caruso D, Stirpe M, Lohmann DR: Multiple lipomas linked to an RB1 gene mutation in a large pedigree with low penetrance retinoblastoma. Eur J Hum Genet 2001, 9:690-694

33. Friend SH, Bernards R, Rogelj S, Weinberg RA, Rapaport JM, Albert DM, Dryja TP: A human DNA segment with properties of the gene that predisposes to retinoblastoma and osteosarcoma. Nature 1986, 323:643-646.

34. Stratton MR, Williams S, Fisher C, Ball A, Westbury G, Gusterson BA, Fletcher $C D$, Knight JC, Fung YK, Reeves BR, et al: Structural alterations of the RB1 gene in human soft tissue tumours. Br J Cancer 1989, 60:202-205.

35. Friend SH, Horowitz JM, Gerber MR, Wang XF, Bogenmann E, Li FP, Weinberg RA: Deletions of a DNA sequence in retinoblastomas and mesenchymal tumors: organization of the sequence and its encoded protein. Proc Natl Acad Sci U S A 1987, 84:9059-9063. 
36. Bookstein R, Lee WH: Molecular genetics of the retinoblastoma suppressor gene. Crit Rev Oncog 1991, 2:211-227.

37. Helman $\sqcup$, Meltzer P: Mechanisms of sarcoma development. Nat Rev Cancer 2003, 3:685-694.

38. Gobin YP, Dunkel IJ, Marr BP, Brodie SE, Abramson DH: Intra-arterial chemotherapy for the management of retinoblastoma: four-year experience. Arch Ophthalmol 2011, 129:732-737.

39. Turaka K, Shields CL, Meadows AT, Leahey A: Second malignant neoplasms following chemoreduction with carboplatin, etoposide, and vincristine in 245 patients with intraocular retinoblastoma. Pediatr Blood Cancer 2012, 59:121-125

40. Abramson $\mathrm{DH}$ : Chemosurgery for retinoblastoma: what we know after 5 years. Arch Ophthalmol 2011, 129:1492-1494.

41. de Graaf P, Goricke S, Rodjan F, Galluzzi P, Maeder P, Castelijns JA, Brisse HJ: Guidelines for imaging retinoblastoma: imaging principles and MRI standardization. Pediatr Radiol 2012, 42:2-14.

42. Meadows AT: Retinoblastoma survivors: sarcomas and surveillance. J Natl Cancer Inst 2007, 99:3-5.

43. Dommering CJ, Marees T, van der Hout AH, Imhof SM, Meijers-Heijboer $H_{\text {, }}$ Ringens PJ, van Leeuwen FE, Moll AC: RB1 mutations and second primary malignancies after hereditary retinoblastoma. Fam Cancer 2011 11:225-233.

44. MacCarthy A, Bayne AM, Draper GJ, Eatock EM, Kroll ME, Stiller CA, Vincent TJ, Hawkins MM, Jenkinson HC, Kingston JE, et al: Non-ocular tumours following retinoblastoma in Great Britain 1951 to 2004. Br J Ophthalmol 2009, 93:1159-1162

45. Marees T, van Leeuwen FE, de Boer MR, Imhof SM, Ringens PJ, Moll AC: Cancer mortality in long-term survivors of retinoblastoma. Eur $J$ Cancer 2009, 45:3245-3253.

46. Acquaviva A, Ciccolallo L, Rondelli R, Balistreri A, Ancarola R, Cozza R, Hadjistilianou D, Francesco SD, Toti P, Pastore G, et al: Mortality from second tumour among long-term survivors of retinoblastoma: a retrospective analysis of the Italian retinoblastoma registry. Oncogene 2006, 25:5350-5357.

doi:10.1186/2045-3329-2-15

Cite this article as: Kleinerman et al: Sarcomas in hereditary retinoblastoma. Clinical Sarcoma Research 2012 2:15.

\section{Submit your next manuscript to BioMed Central and take full advantage of:}

- Convenient online submission

- Thorough peer review

- No space constraints or color figure charges

- Immediate publication on acceptance

- Inclusion in PubMed, CAS, Scopus and Google Scholar

- Research which is freely available for redistribution 